\title{
Sveta noč spanca, ideja otroka in respiratorna (po)etika miru Lenart Škof
}

Znanstveno-raziskovalno središče Koper, Inštitut za filozofske študije, Garibaldijeva 1, 6000 Koper https://orcid.org/0000-0003-2199-3550

lenart.skof@zrs-kp.si

Članek obravnava Hölderlinovo in Claudelovo pesništvo ter Bachelardovo poetiko imaginacije v luči ideje otroka, svetosti otroškega spanca ter s tem povezane respiratorne (po)etike miru. Vprvem delu se ukvarja z vprašanjem prastarih redov otroškosti, kakor se pojavljajo v izbranih Hölderlinovih himnah, pri čemer se analize osredotočajo na povezavo materinskih genealogij in ideje otroka v izbranih Hölderlinovih verzih nedokončane "Himne Madoni " ter nekaterih drugih njegovih delih. Temu je dodana interpretacija nekaterih Heideggrovih wvidov, kakor se navezujejo tako na Hölderlinovo poetiko, kakor tudi na Heideggrovo lastno mišljenje rojstvenosti in miru. V drugem delu se prek Bachelardove poetike sveta kot kozmične zibke pomaknemo v svet, v katerem je otroški spanec povezan s kozmičnim ritmom dihanja, kar odpira novo atmosfero miru prebivanja. S tem povezane so tudi navezave na Merleau-Pontyja, ki je deloval pod močnim Bachelardovim vplivom. Vtretjem in sklepnem delu pa se na sledi Claudelovega pesništva, zlasti njegove slavilne ode "Magnifikat" ter njegove ideje o nesmrtnosti otroka, pomaknemo proti (post-)krščanskemu okviru premišljevanja in idejo otroka, navežemo tudi na filozofijo Luce Irigaray, s posebnim poudarkom na vprašanju razmerja med Marijo kot materjo in Jezusom kot otrokom.

Ključne besede: literatura in ideja otroka / poetika miru / Marija in Jezus / Hölderlin, Friedrich / Claudel, Paul / Bachelard, Gaston / Heidegger, Martin / Irigaray, Luce 


\section{Praetični redovi otroškosti v Hölderlinovem pesništvu ${ }^{1}$}

Ko bi morali dihati svoj otroški spanec

v svetósti nočnega miru

ste bili prebujeni s srdom sveta.

Odtrgani od sanj in svojih mehkih živalic

ste bili rojeni v neko drugo svetlobo in zrak.

Kdo vas bo zaščitil? Kdo vam bo tkal sanje?

Otroci, otroci, otroci.

V Razjasnjenjih ob Hölderlinovem pesništvu se Heidegger med branjem pesnitve Spomin dotakne Hölderlinove nedokončane Himne Madoni (An die Madonna) ${ }^{2} \mathrm{v}$ kateri srečamo naslednje verze, posvečeni Kraljici Mariji (vv. 48-53):

--- in ko v sveti noči

nekdo pomni prihodnost in nosi

skrb za brezskrbno speče,

sveže vzcvetajoče otroke,

ti smehljaje se prideš in vprašaš, česa, koder

ti bila bi kraljica, bi se bal. (Hölderlin, Sämtliche 220-221) ${ }^{3}$

V zgornjih verzih se razpira atmosfera svetósti noči kot zaščitnice mirnega spanja brezskrbnih otrok. V njej Hölderlin v ta svet obenem poetično vpelje feminino načelo, ki tu označuje Kraljico Marijo, Jezusovo mati, varujočo svet smrtnikov pred vdorom zla, ki povzroča strah, trpljenje in uničenje. Skozi sinhronistični poetični princip je $\mathrm{v}$ tej himni Marija postavljena v kontekst boginje Gaje kot grške Matere

${ }^{1}$ Pričujoči članek je nastal v okviru programa ARRS P6-0279.

${ }^{2}$ Renate Böschenstein v svoji razpravi o Hölderlinovi Himni Madoni opozori na dejstvo, da v nemškem prostoru ime "Madona« kot ime Matere Božje še ni bilo širše prisotno pred koncem 18. stoletja, v Adelungovem slovarju iz leta 1798 je tako še ni (Böschenstein 192). Obenem avtorica med vplivi na Hölderlina omenja marijansko liriko Celeusma Marianum Jacoba Baldesa, ki jo je prevedel in nemškemu prostoru predstavil Herder leta 1795/96. Ta je v svojem ciklusu Maria Marijo označil z izrazom "kraljica» ter jo predstavil kot "zaščitnico otrok" (193).

${ }^{3}$ Prvi del kitice se opira na prevod Vida Snoja iz Razjasnjenj (Heidegger, Razjasnjenja 103). Za pričujoči namen je bil prevod le malenkostno spremenjen s strani avtorja. Vidu Snoju se obenem zahvaljujem za dragocene nasvete pri prevajanju te Hölderlinove himne. 
Zemlje, germanske matere Narave (Hertha) ${ }^{4}$ pa tudi Antigone in Diotime ter sorodnih femininih matric pri Hölderlinu. Kot sem pokazal v svojih Antigoninih sestrah, so te matrice femininosti varuhinje starih matriksialnih ali materničnih-rojstvenih redov. $\mathrm{V}$ razmerju do grških maskulinih-očetovskih genealogij (denimo Uran-Kronos-Zevs) ter tudi judovsko-krščanskega okvira Božjega kot očetovske paradigme, je Marija analogno Gaji zdaj tista, ki lahko ščiti otroke pred vsakršnim srdom - najsibo bogov ali pa ljudi. Marija tako skozi Hölderlinovo himno označuje lik Matere Božje, ki ga najdemo v številnih cerkvah, med drugim tudi v izjemni upodobitvi v Baziliki Marije Zavetnice $s$ plaščem na Ptujski gori. Njena poglavitna naloga je tako zaščita otrok in mater ter tudi posvečene rojstvene zveze med materami in hčerkami. Kot ugotavlja Otto,

[v] materinskih zemeljskih boginjah tako prepoznamo varuhinje in predstavnice častivrednih redov, ki med seboj povezujejo starše, otroke ter sestre in brate. V njih so posvečene tudi različne rojstne pravice otrok. (Otto 32)

$\mathrm{Na}$ te starodavne in nenapisane zakone predolimpskih boginj (boginja Zemlja, Erinije, Evmenide kot hčere Noči, Afrodita...) se je sklicevala že Sofoklova Antigona, ko je s pietetnim pokopom brata želela svet zaščititi pred vdorom in nadvlado protietičnih in antimatriksialnih načel, ki jih je zastopal vladar Kreon. ${ }^{5}$ Verzi 39-42 iz Himne Madoni prinašajo prav to spoznanje:

Kajti dobre so postave, a

kot zobje zmaja režejo

in morijo življenje, kadar jih v srdu ostri

kak neznatnež ali pa kralj. (Hölderlin, Sämtliche 220)

Hölderlinovo pesništvo je tako izjemno občutljivo, ko gre za spoštovanje teh prastarih redov: v Slovesnosti miru (vv. 118-129), pesnitvi posvečeni Kristusu, čudovito občutljivo pesni o praetični diadi matere in otroka, in njunega posvečenega miru, ovitega v atmosfero svete sape:

${ }^{4}$ Prim. tu boginjo narave Nikrmano, kakor nastopa v tradiciji naravoverstva Zahodne Slovenije, v pričevanju Pavla Medveščka: „Dober in pošten človek, ki spoštuje vsa živa bitja in vse, kar je okoli njega, pa tudi v podzemlju in na nebu, se nima ničesar bati, ker je tudi on del vsega tistega, za kar skrbi Nikrmana." (Medvešček-Klančar 110) Tu dolgujem posebno zahvalo Cirili Toplak, ki me je s svojim delom, posvečenim slovenskemu naravoverstvu, seznanila s to tradicijo.

${ }^{5} \mathrm{~S} »$ kraljem« je tu verjetno mišljen prav Kreon. 


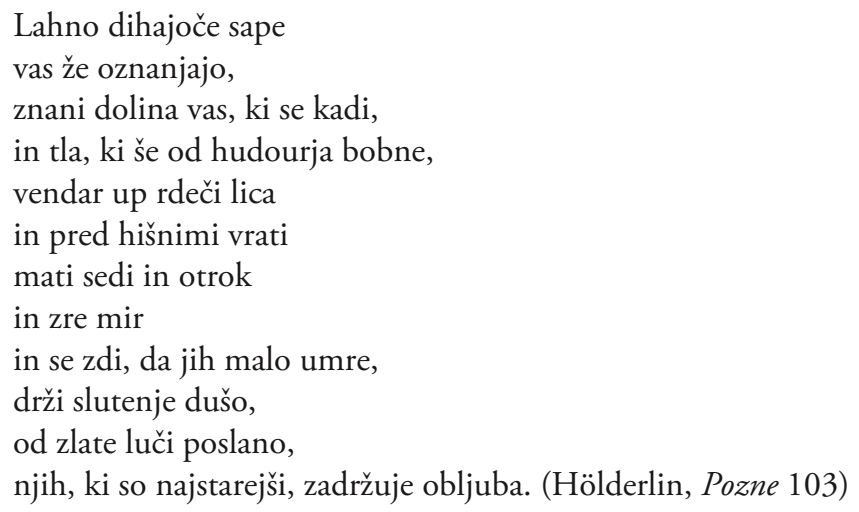

Elementi, ki se nakazujejo v teh stihih, združujejo stare matriksialne in kozmične-spiritualne redove (utemeljene na sveti sapi ali svetem dihu) - redove, ki s tem predhodijo tako poznejšim maskulinim kakor tudi dih pozabljajočim »duhovnim" nanosom. Med njimi je v ospredju podoba matere in otroka, sedečih pred hišnimi vrati in zrečih $\mathrm{v}$ mir prebivanja. Heidegger v daljavi svoje filozofije prepozna obe genealogiji in nanju namiguje v svoji interpretaciji pesnitve Spomin, v kateri "zazibavajoče/uspavajoče« sape iz štiriindvajsetega verza namigujejo na ritem miru enakomernega dihanja ter hkrati umirjenega ritma otroškega spanca v zibki:

Ob praznikih hodijo

tod rjave žene

po svilenih tleh,

v marčevem času,

ko sta enaka noč in dan,

in čez zložne brvi,

težke od zlatih sanj,

vlečejo uspavajoče sape. (Hölderlin, Pozne 191) ${ }^{6}$

V okviru našega branja te pesnitve pri Hölderlinu prav tople zazibavajoče sape, ki se pojavijo $s$ prihodom $s$ soncem ožarjenih žensk ob času pomladnega enakonočja, napotujejo na poravnavo sveta v miru (Škof, Etika 159). Z dodanim interpretativnim korakom in vključenim sinhronističnim branjem teh verzov lahko zdaj te sape namigujejo na dar, ki nam ga prinašajo ženske kot nosilke svetega diha rojstvenosti (kot simbola sodihanja matere in otroka $\mathrm{v}$ maternici, širše tudi sodihanja

${ }^{6}$ Vid Snoj v Poznih himnah prevaja verz "Einwiegende Lüfte ziehen« z "vlečejo uspavajoče sape«, medtem ko v Razjasnjenjih ob Hölderlinovem pesništvu uporabi prevod "vlečejo zazibavajoče sape«. 
v okviru Svete Trojice). ${ }^{7}$ Tudi Heidegger tako ve, da so te kozmično-feminine sape povezane z rojstvenostjo, saj

[s]ame niso nikakršen prazen kraj brez »atmosfere«. Obdane in prevete so $s$ sapami, ki zazibavajo. [...] In vendarle - zazibavanje ohranja v zibki, ki spada $\mathrm{k}$ rojstvu. [...] Zazibavajoče sape morajo bistveno sodoločati izvor bistva polboga, tj. pesnika. (Heidegger, Razjasnjenja 104) ${ }^{8}$

Filozofsko-teološke genealogije, ki so izpodrinile te stare kozmološko-feminine matrice bivanja in dihanja in jih nadomestile z maskulinimi redovi bogov in spremljajočega duhovnega principa, so, kot bi rekla Luce Irigaray, postale oponašalke življenja ter niso več zmogle $\mathrm{v}$ polnosti ščititi rojstvenosti in prinašati prvobitnega miru prebivanja. ${ }^{9} \mathrm{Da}$ bi se povrnili $\mathrm{v}$ to izvorno konspiracijo sodihanja $\mathrm{v}$ rojstvenosti, bo potreben prehod $\mathrm{v}$ novo epoho, ki ga Irigaray razume kot nastop Tretje dobe - feminine dobe Diha (ali elementarno-materialno prebujenega Sv. Duha), ki bo po dobi Očeta ter dobi Sina (z intervencijo Marije) tudi v smislu spolne razlike sklenil eshatološki lok prebivanja. ${ }^{10}$ A povrnimo se še za trenutek k Heideggru. V svojem izjemno tenkočutnem premisleku Gradnja Prebivanje Mišljenje je povezavo rojstvenosti in zibke povzel v okviru pripovedi o bistvu stare schwarzwaldske domačije: »[K]o so naši predniki svoje bivanje uprostorili v ubranosti s kozmičnimi redovi Četverja, so v sobi s prav posebno skrbnostjo določili posvečene prostore za otroško posteljo." (Heidegger, Predavanja 171) S tem je Heidegger povezal rojstvenost in idejo otroškega spanca pod obnebjem posvečenosti (otroškega) prebivanja - ki ga mislec v njegovi izvornosti povezuje z mirom:

Poslušajmo še enkrat prigovor govorice: starosaško wunon, gotsko wunian pomenita tako kot stara beseda bauen, ostajanje, zadrževanje. Gotsko wunian razločneje pove, kako je izkušeno to ostajanje. Wunian pomeni: biti pomirjen,

${ }^{7}$ Več o tem in tudi o možni navezavi na indijsko kulturo diha (prānāyāma) preko Hölderlinovih bogatih nastavkov mišljenja in pesnjenja Inda gl. mojo Etiko diha (155 isl). Prim. tu tudi himno Spomin, 79: "Zdaj pa so k Indijcem / Šli možje, ...«. O sodihanju Svete Trojice več v nadaljevanju (glej Škof, Antigonine 266 in 274).

${ }^{8}$ Prim. Hölderlinove verze iz Grčije: »Bog nosi oblačilo / In spoznanjem se skriva njegovo obličje / In prekriva z umetnostjo sape." (Heidegger, Razjasnjenja 143)

${ }^{9}$ Irigaray tako pravi: „Oponašalec življenja ne diha ali ne diha več: zrak jemlje drugim, svetu." (Irigaray, Marijina 19). Odveč je pripomniti, da sleherna (institucionalna) religija, ki ne zmore $\mathrm{v}$ polnosti upoštevati teh prastarih nenapisanih redov, tvega $\mathrm{v}$ razmerju do otrok in femininega načela zdrs v sámo bližino diaboličnega.

${ }^{10}$ Gl. več o tem v Škof, "Naproti« 73-81. Z elementarnim tu mislimo na izvorno kozmično konstelacijo diha kot spiritualno-materialnega načela, mišljenje Tretje dobe pa se navezuje na teološko misel Joahima iz Fiore ter izjemnega Amalrika iz Bene. 
umirjen, ostajati v miru. Beseda Friede meni prosto, das Freie, das Frye, in fry: biti obvarovan pred škodo in ogroženostjo, obvarovan - pred ..., tj.: prizanešen. [...] Prebivati, umiriti se, pove: ostati ograjen $\mathrm{v}$ prosto, tj. v prosto, ki vsako prizanese v njegovem bistvu. (Heidegger, Predavanja 158)

Otroški spanec je tako zaščiten s starimi kozmološkimi redovi in odmeva skozi Hölderlinovo in Heideggrovo pesnjenje in mišljenje. Postavljen je $v$ atmosfero miru in obvarovanosti pred hudim: to je svet otroškosti in prizanašanja $v$ razmerju do zla ali hudega. Sveta noč spanca in mir prebivanja smrtnikov sta skozi prvinskost praetičnih redov femininosti in kozmoloških elementov diha in zraka tako tesno povezana z rojstvenostjo in sámo idejo otroka, hkrati pa seveda presegata zgolj idejo otroka ter nakazujeta pot miru v okviru sobivanja vseh smrtnikov. Morda to sovpadanje etike in ideje otroka še najbolje ponazarja trditev Hansa Jonasa, ki takole zapiše v svojem poglavju »Otrok - praobjekt odgovornosti«, pri čemer seveda meri tako na idejo otroka kot zahtevo miru kakor tudi na idejo neke nove etike, utemeljene $\mathrm{v}$ nenapisanih maksimah etike diha:

$[\mathrm{N}]$ ovorojenček, katerega golo dihanje usmerja na svojo okolico brezprizivni Moraš!, namreč: se zanj zavzeti. (Jonas 235)

Za Luce Irigaray, ki premišljuje iz obzorja Bachelardove elementarne filozofije, se prav v spanju novorojenčka kaže neka resnica, ki nam je ponavadi $\mathrm{v}$ filozofiji ostajala skrita: poleg tega, da novorojenčki veliko spijo, se v njihovem spancu na nek poseben način kažejo tudi utrinki prebivanja v svetu, pri čemer Irigaray razmerje med otrokom in okolnim svetom že misli na način (radikalne) subjektivnosti otroka:

Vse to si je zares težko zamisliti in tako kot Zaratustra, ki v iskanju načina izoblikovanja novega sveta prebiva v visokih gorah, tudi novorojenček veliko spi. Medtem ko spi, se včasih nasmehne, kakor da bi odkril rešitev neke uganke, oziroma žari od modrosti kot kak mali Buda; spet drugič pa tudi krikne v neugodju, ko se morda sreča z neko težavnostjo v svojem bivanju in ne le zaradi lakote ali neugodja v želodcu - kot bi odrasli na splošno radi razumeli njegov jok. Zato mu ne priznavajo ontološke pripadnosti in ga omejujejo na univerzum potreb, iz katerih se je že osvobodil s tem, ko je nase vzel tveganje prihoda na svet. (Irigaray, To Be Born 9) ${ }^{11}$

${ }^{11}$ Prim. Nietzschejevega Zaratustro, ki premišlja in pesni prav skozi idejo nove respiratorno-otroške paradigme prihodnosti: „Nedolžnost je otrok, in pozaba, začetek od kraja, igra, iz sebe se vrteče kolo, prvi gib, sveti ja. [...] Resnično, kakor tisočerni otroški smeh prihaja Zaratustra v vse mrtvašnice in se smeje vsem tem nočnim in 
Ta misel nas bo pozneje vodila $\mathrm{k}$ premisleku o smislu Jezusovega prihoda na svet - toda najprej in določno nujno z vidika ideje boga kot otroka, takoj zatem pa tudi z vidika ideje nekega ontološkega dispozitiva, ki edinole lahko otrokom podeljuje njim samolastni smisel prebivanja. A tu se moramo zaenkrat še ustaviti in na sledi predhodno razvitih misli ugotoviti, da se Hölderlinova praetična »skrb za brezskrbno speče in sveže vzcvetajoče otroke« tako poveže z etičnim imperativom elementarne zaščite otroškega prebivanja v spanju novorojenčka, otroka, in pozneje tudi slehernika. To misel želimo $\mathrm{v}$ drugem delu pričujoče razprave najprej povezati z novo filozofijo in poetiko elementov, kakor jo je v svoji tetralogiji posvečeni poetiki in imaginaciji zraka, ognja, zemlje in vode predstavil Gaston Bachelard ter v stiku z njegovo mislijo tudi Maurice Merleau-Ponty.

\section{Bachelardova poetična imaginacija sveta kot kozmične zibke}

O ti pesem nevidna, dih moj!

ki za vesoljstvo zamenjuješ nenehno bit svojo. Protipol tvoj, v katerem me z ritmiko dokazuješ. (Rilke, »Soneti« 73)

Gaston Bachelard je s svojo tetralogijo, posvečeno štirim elementom (zrak, ogenj, zemlja in voda), poleg Heideggrove pozne misli tisti, ki je v zgodovini novejše zahodne filozofije pripravil prostor za vrnitev $\mathrm{k}$ predsokratskemu mišljenju elementarno-materialne imaginacije ter z njo povezanega prebivanja v svetu. Med leti 1938 in 1943 se je tako intenzivno ukvarjal z elementarno filozofijo in napisal štiri izjemna dela, ki prečijo široka področja filozofskega mišljenja, psihoanalize in literature: Voda in sanje, Zemlja in sanjarjenja volje, Zrak in sanje ter Poetika ognja (tej je sicer predhodna zgodnejša Psihoanaliza ognja). ${ }^{12}$ Bachelard je tako tlakoval pot, po kateri sta pozneje hodila temeljna

mrliškim čuvajem in kdor še rožlja z mračnimi ključi. [...] Zdaj bo iz rakev vrel otroški smeh, zdaj bo zmeraj zmagoslavno prihajal močan veter nad vso smrtno utrujenost: za to si nam ti sam porok in prerok! « (Nietzsche 29, 159)

${ }^{12}$ Dela so po vrsti izšla v originalu kot: L'Eau et les rêves, essai sur l'imagination de la matiére (1942); L'Air et les songes, essai sur l'imagination du mouvement (1943); La terre et les rêveries de la volonté, essai sur l'imagination de la matiére (1943); ter Fragments d'une Poétique du Feu (1988). Temu posthumno izdanemu delu o ognju predhodi La Psychoanalyse du Feu (1938). Vse odlomke iz Bachelardovega L'Air et les songes navajamo po uveljavljenem angleškem prevodu v Bachelard, Air. Za francoski izvirnik gl. Bachelard, L'air. 
misleca elementov, Maurice Merleau-Ponty in Luce Irigaray, sočasno pa je po tej poti že stopal tudi Heidegger na prehodu v svojo pozno misel. Če se zdaj usmerimo na Bachelardovo delo Zrak in sanje, imamo v njem priložnost spoznati misleca, ki želi preko premisleka o elementu zraka in z njim povezanih sanj prodreti do skrivnosti noči in spanca. Takole pravi o spancu in naših sanjah povezanih z letenjem - in tu imejmo pred seboj Hölderlinovo in Heideggrovo konstelacijo svetosti noči in miru (otroškega) spanja:

Dober spanec je tisti, v katerega smo zazibani ali nošeni in imaginacija nam jasno da vedeti, da smo zazibani in nošeni od nečesa in ne od nekoga. Vtem ko spimo, naseljujemo Kozmos; zibani smo od vode; nošeni smo v zraku - ki ga dihamo z ozirom na ritem našega lastnega diha. To je spanec otroštva, ali vsaj miren spanec mladosti, ko nočno življenje tako pogosto zasliši povabilo $\mathrm{k}$ potovanju, da bi se odpravili na brezmejno pot. (Bachelard, Air 36)

Bachelard tu ve, da je ritem spanja in dihanja uglašen $z$ ritmom Kozmosa: v tem je skrita neka misel, ki se odmika od v krščanstvu uveljavljenih teoloških shem stvarjenja kot creatio ex nibilo in s tem povezanih teoloških tematizacij prisotnosti zla $\mathrm{v}$ svetu in s tem klasične teodiceje. Zdi se, da je v spancu, še posebej pa v spancu otrok, skrita starodavna resnica, ki nam je dostopna samo preko imaginacije in ki je ne moremo ubesediti na način neke filozofske ali teološke resnice: ko opazujem mirno spečega otroka, in ko se povežem z rahlo dihajočim in nežno utripajočim telesom tega s sveto Sapo narave povezanega bitja, ne morem te misli povezati z mislijo o razcepu med stvarnikom in bivajočim, ali med dobrim in zlim. Pred menoj se razprostre atmosfera miru, ki jo zdaj naseljujem skupaj s tem otrokom. $S$ tem, ko sem v mislih združen z bitjem srca in dihom spečega otroka, se v meni razodene pradavni impulz pozabljene in $s$ številnimi nanosi bivajočnosti prekrite etike diha ali sodihanja vsega, kar živi. Povežem se z njim v ubrano sodihanje miru, ki mi je bilo sicer odvzeto. To je način prebivanja $\mathrm{v}$ miru, ki ga lahko dosežejo sanje, in ki nam je tako dostopen le skozi imaginacijo: $v$ njem sem povezan z bivanjem, ki je lastno nebeščanom in ki je zavarovano pred zlom tega sveta. $S$ temi besedami se Bachelard hkrati pomakne k Shelleyjevemu pesništvu. Shelley je zanj pesnik, ki je resnično prebival v "zibki vetra« (Bachelard, Air 42), pri čemer tudi pri slednjem - tako kot pri Hölderlinu - vidimo odmev atmosfer prebivanja z Vzhoda: 
Naša barka je albatros, katerega gnezdo je daljni Edenski vrt škrlatnega Vzhoda; In sedeli bomo med njenimi krili, medtem ko bodo Noč in Dan, in Neurje in Mir, sledili svojemu lêtu. (Shelley, "Epipsihidij«; nav. po Bachelard, Air 42) ${ }^{13}$

Za Bachelarda se v Shelleyjevi poetiki jasno izraža imaginacija nežnega zibanja in zanj je njegova poetika "utemeljena na zibanju prostora: zanj je svet brezmejna zibka - kozmična zibka - iz katere ves čas poletajo sanje "(Bachelard, Air 44). Skozi parafrazo komentarja Louisa Cazamaniana ob Shelleyjevi »Eolski harfi« se lahko Bachelard zdaj slednjič pomakne še za stopnjo naprej in zapiše:

Shelleyjevo celotno bitje vibrira s tisočerimi senzoričnimi impulzi, ki jih narava pošilja $\mathrm{v}$ njegovi smeri in ki morda na strunah univerzuma proizvajajo tisti "idealni dih zraka", ki bi lahko hkrati bil duša slehernega bivajočega in tudi Bog vsega. (Bachelard, Air 45)

S to izjemno mislijo smo zdaj na sami meji nečesa, kar je uspel v polnosti ubesediti šele Merleau-Ponty s svojo mislijo o kozmično-ontološki povezavi (vinculum) človeka, narave in Boga.

Finski filozof Petri Berndtson je v svojem prispevku "Navdih in izdih biti: brezmejna pljuča in kozmično dihanje kot izvori sanj, pesništva in filozofije« prvi določno pokazal na položaj človeka v okviru respiratorno razumljenega kozmosa ter $s$ tem na dinamiko diha, kakor le-ta preči mejo med pesništvom in filozofijo (Berndtson, »The Inspiration «). Svojo interpretacijo Bachelarda utemelji na načelu poslušanja sveta, ki je lastno pesnikom in filozofom: tako kot pesnikom govori narava, govori nam imaginacija. Imaginacija, $s$ katero pesnik prihaja $v$ stik s svetom, pa je zdaj subtilno-elementarne ali "materialne« narave (v starem elementarno-kozmičnem smislu), saj je $\mathrm{v}$ neposrednem stiku s primarnimi elementi vode, zemlje, ognja in vetra. Tako Hölderlin kot Heidegger sta se nahajala $\mathrm{v}$ tem elementarnem svetu prebivanja in enako velja za Irigaray. V enem izmed najlepših odlomkov nasploh pri Heideggru (ki so mu pravzaprav od podobnih filozofskih opisov še najbližji čudoviti stari upanišadski opisi prebivanja v svetu) se Četverje razodeva na način vznikanja elementov zemlje, vode, ognja (svetlobe ali žarenja) in seveda etra/diha:

${ }^{13} \mathrm{~V}$ izvirniku: "Our bark is an albatross, whose nest / Is a far Eden of the purple East; / And we between her wings will sit, while Night, / And Day, and Storm, and Calm, pursue their flight." 
"Na zemlji« že pove: "pod nebom«. Z obojim skupaj je menjeno "ostajanje pred bogovi« in vključuje »skupno služnost ljudi«. Iz izvorne enotnosti spadajo $v$ eno štirje: zemlja in nebo, bogovi in smrtniki.

Zemlja je služno nesna, cvetoče zoreča, razprostrta v kamenju in vodovju, vznikajoča za rastline in živali. Ko rečemo zemlja, z njo že mislimo ostale tri, vendar ne pomišljamo ubranosti štirih.

Nebo je obodni hod sonca, podobo menjajoči tek meseca, tavajoči sij zvezd, so letni časi in njihovi preobrati, svetloba in somrak dneva, tema in jasnina noči, gostoljubnost in negostoljubnost vremena, poti oblakov in modrilna globina etra. Ko rečemo nebo, potem z njim mislimo tudi druge tri, vendar ne pomišljamo ubranosti štirih. (Heidegger, Predavanja 159)

Slednjič se vse omenjene teme te elementarne vpotegnjenosti v svet prebivanja izrazijo v izjemnem odlomku Merleau-Pontyja, ki je v svojo filozofijo in ontologijo vključil vse ključne Bachelardove uvide. Merleau-Ponty, ki je v temelju elementarni(-respiratorni) mislec, se v svoji fenomenologiji zaznave dotakne fenomenologije spanca in zapiše naslednje misli.

[S]panec nastopi, ko določena prostovoljna drža od zunaj sprejme potrditev, ki jo je pričakovala. Jaz sem dihal počasi in globoko, da bi priklical spanec, in lahko bi rekli, da moja usta kar naenkrat začno sodelovati z nekimi velikanskimi zunanjimi pljuči, ki vdihujejo in izdihujejo, tako da določen ritem dihanja, ki sem si ga ravnokar zaželel, postane moja bit sama, nakar spanec, ki je bil do sedaj le pomen, postane situacija. (Merleau-Ponty, Fenomenologija 225)

S tem se Merleau-Ponty nedvoumno naveže na Bachelardovo mišljenje, pri čemer na svoj izviren fenomenološki način pokaže na tesno povezavo med ontologijo bivanja in njo utemeljujočim ali bistvenim delom - ontologijo spanja. Še več, v njegovem znamenitem eseju „Otrokov odnos z drugimi« je otroško telo enako kot pri Jonasu razumljeno kot utemeljeno na dihu in s tem označeno kot "respiratorno telo" (Merleau-Ponty, The Primacy 122). V svojih dolgo neobjavljenih razpravah o naravi s Collège de France iz let $1952-60^{14}$ je - docela na sledi Hölderlinove, Heideggrove in Bachelardove poetike sveta - MerleauPonty kot katoliško navdahnjeni mislec zdaj povezal teme človeka, narave in Boga $\mathrm{v}$ neksus oziroma tako imenovani vinculum, s čimer je na idiosinkratični način kot prvi zvezal v celoto novega ontološkega premisleka tri velike teme - naturalizem, humanizem ter teizem:

${ }^{14}$ Gl. Merleau-Ponty, »Themes« 71-199. Navajamo po uveljavljenih angleških prevodih. Za francoska izvirnika gl. Merleau-Ponty, La Nature. 
Obstaja neka unikatna tema filozofije; neksus, vinculum »Narava« - ¿Človek«"Bog«. Narava kot list Biti, in problemi filozofije so koncentrični. (MerleauPonty, Nature 204) ${ }^{15}$

Bitja sveta in narave, ter bog(ovi) zdaj prehajajo drug v drugega, in če pobliže prisluhnemo tej misli kozmičnega prepletanja, se to godi skozi in preko nakazovanja posredništva kozmičnega Kristusa. ${ }^{16} \mathrm{Za}$ Merleau-Pontyja in njegovo filozofijo mesa zdaj velja, da "utelešenje spremeni vse« (Saint Aubert 375). Takole pravi o njegovi misli Saint Aubert: "Kajti vse zareze, vse razlike, tudi ontološke, so v nas samih: upravičeno je treba utelešenje vzeti resno.« (382. Tu se MerleauPontyjeva misel zelo približa pesništvu Paula Claudela, ${ }^{17} \mathrm{~s}$ katerim je bil v tesni, lahko rečemo celo mistični povezavi, in v sklepnem delu naše razprave želimo prek te povezave na novo premisliti morda temeljno izmed vseh vprašanj - vprašanje ideje nesmrtnega otroka in $s$ tem povezane ideje boga.

\section{Claudelova lirika, nesmrtnost ideje otroka in Otrok Jezus}

V tretji izmed Pet vélikih od z naslovom "Magnifikat "Claudel poveličuje Gospoda na način zahvalne pesniške govorice ob rojstvu hčerke. Prisluhnimo najprej njegovi slavilni govorici:

Moj Bog, ki si v začetku vsega in tudi v lastnem začetku postavil očetovstvo, bodi hvaljen, ker si mi dal tega otroka, in skupaj z mano ustvaril nekaj, s čimer Ti bom mogel povrniti dar življenja: zdaj sem ji oče skupaj s Tabo.

Nisem jaz tisti, ki je rodil, nisem tisti, ki je bil rojen.

$[\ldots]$

Bodi hvaljen, ker ne živim več sam,

In je iz mene izšlo bitje in prebujenje nesmrtnega otroka $[\ldots]$

${ }^{15}$ Izraz »vinculum « je v zgodovini filozofije v tem pomenu prvič omenjen pri Giordanu Brunu, gl. o tem njegovo razpravo "Splošno poročilo o povezavi«v Bruno, Cause.

${ }^{16} \mathrm{Tu}$ se opiram na interpretacijo Christopherja Ben Simpsona iz njegove Merleau-Ponty and Theology.

${ }^{17}$ Gl. o tem izjemno doktorsko disertacijo Petrija Berndtsona o Merleau-Pontyju in njegovih tesnih navezavah na Bachelarda in Claudela (Berndtson, Phenomenological). O poetiki Literature dihanja gl. izjemno monografijo Stefanie Heine Poetics of Breathing: Modern Literature Syncope. 
To si potemtakem ti, priseljenka - končno lahko vidim tvoj obraz:

kot bi ravnokar vzel izpred Boga zrcalo in bi v njem še ne bilo nobenega drugega odseva.

$[\ldots]$

O moja hči! O otročiček, podoben bistvu moje duše, ki mu moram zopet postati podoben

$[\ldots]$

O otrok, rojen na tujih tleh! O rožno srčece!

O sveženjček, bolj svež kot velik šopek

belih lilij! (Claudel 59, 60, 61; poudarek je avtorjev)

V zgornjih verzih sta v ospredju dve pomembni ideji: prvič, ideja absolutne ontološke pripadnosti otroka, ki mu Claudel - tako kot Irigaray podeli polno bivanjsko razsežnost tako v razmerju do staršev kakor tudi do Boga; in drugič, jasno izražena Claudelova pripadnost rojstvenim genealogijam, s katerimi se zoperstavlja tendencam, ki bi želele idejo otroka v razmerju do drugega omejiti ali reducirati na drugotno vlogo v razmerju do starša ali do Boga. Claudel s tem razpira polje čiste ali neskončne ljubezni do otroka, ki smo mu v Antigoninih sestrah nadeli ime genealoške ljubezni, tudi v navezavi na dinamiko trinitaričnosti, ki je prisotna v Claudelovi misli otroka. Takole smo zapisali:

Ko oče ali mati na ta trinitarični način ljubita sina ali hčerko, se v svoji ljubezni $\mathrm{v}$ polnosti predajata svojemu otroku, tudi skozi različne moduse skrbi zanj(o). Toda ta odnos ni hierarhičen, saj se njuna popolna in brezpogojna ljubezen napaja natanko iz vsega tistega, česar sama in vsak zase nikoli nista posedovala ali bila in kar tako v enaki popolnosti sama prejemata od otroka: $\mathrm{v}$ tem je bistvo horizontalne transcendence odnosa in izmenjave ljubezni - kot procesa vzajemne podaritve in s tem daru medsebojne ljubezni med enim in drugim (kot nečesa tretjega). To (pra)obliko ljubezni bi lahko poimenovali z izrazom genealoška ljubezen. (Škof, Antigonine 224 isl.) ${ }^{18}$

Claudel se v svoji na prvi pogled maskulini genealogiji navezuje na dve figuri očetovstva - Božjo in svojo, in morda bi na sledi matriksialnih genealogij sprva lahko pomislili, da je krivičen do matere njegove hčerke. Vendar se Claudel močno zaveda najbližje prisotnosti matric femininosti, saj sebi (v nasprotju z grškimi bogovi - denimo Zevsom) ${ }^{19}$ kot moškemu odreka zmožnost roditi, kakor tudi biti

${ }^{18}$ Več o tem v poglavju »O oblikah čiste ljubezni: starši in otroci« omenjene knjige (213-226).

${ }^{19}$ Glej mit o Zevsovem použitju boginje Metide ter rojstvu Atene iz Zevsa samega. Prim. tudi sledeče verze iz Ajshilove Oresteje: "Tako imenovana mati ne rodi, / temveč 
rojen: še več, v verzih, ki sledijo, je Claudel jasen, da je Bog, da bi prejel Sina, "potreboval Marijo in Marija dolgo vejo svojih prednikov" (Claudel 59), v Marijinem obiskovanju pa Jezusovo mater označi kot večno božjo modrost:
Mati svetega Janeza Krstnika zre v mater mojega Boga!
O srečna ti, Elizabeta, ki si v prvem Stabatu videla Marijo,
večno božjo modrost, tedaj ko je Magnifikatu dala melodijo! (Claudel 118)

Hčerka, ki je Claudelu celo bolj sveža kakor šopek belih lilij - cvetlic Marijine nedolžnosti in čistosti $-s$ tem postane subtilna označitev enigme ideje otroka, za katero še nimamo imena in ki jo moramo še premisliti in pri tem se bomo oprli na mariologijo v okviru misli Luce Irigaray, ključne (post-)katoliške filozofinje sodobnega časa.

Luce Irigaray je lucidno ugotovila, da je človeštvo potrebovalo dve ženski, da je na svet lahko prišel Odrešenik: Marijo in njeno mater Ano. V Marijini skrivnosti je zapisala, da je v razmerju med Marijo in Jezusom in hkrati z vidika odrešitve sveta, »iz ženskega dihanja rojeno moško« (Irigaray, Marijina 14). Vendar je tu zdaj pomembno to, kako Irigaray Marijino devištvo in njeno čistost poveže z idejo otroka:

Ko je bila Marija telesno še devica, je še v celoti ohranjala ženskost deklice. Tudi ko je bila glede na svojo genealogijo samostojna, posebno v razmerju z materjo, njeno telo in njen dih intimno še nista bila pomešana z dihom in telesom kakega drugega človeka. Marijo samo s seboj in s svetom povezuje njeno dihanje. Odrašča, je že v puberteti, vendar še vedno diha kot deklica ali skoraj še kot deklica. Njeno telo se začenja vznemirjati in zadrževati dih, navdih, $\mathrm{v}$ delih telesa, ki so manj v stiku s celoto. In v tem trenutku nastopi angel. (Irigaray, Marijina skrivnost 11)

Najprej je pomembno, da je zgornje besede zapisala ženska, ki pripada katoliški in s tem marijanski tradiciji. V svoji Marijini skrivnosti Irigaray opisuje, kako v bogoslužju in v teologiji pogreša močnejši poudarek na liku Marije kot temeljnega pogoja utelešenja. Marija, kakor jo razume in opiše Irigaray, je hkrati bližje ideji otroka/deklice kot ideji odrasle ženske. V teologiji se izjemno redko, če sploh, srečamo z mislijo na Marijo in Jezusa kot deklico in dečka - ki bi torej duhovno še prebivala v bližini ideje otroka, četudi v razmerju Božje matere in Božjega sina. In

samo redi / vsajeno kal. / Rodi ploditelj, ona brst gosti / in ga ohrani, če ga ne uniči / kak bog. Imam dokaz za to, kar pravim: / oče lahko brez matere rodi.« (Ajshil, Oresteja 144). 
njuno posebno razmerje zdaj nakazuje prihod na svet neke nove oblike transcendence - to je "utelešene transcendence» (Irigaray, Marijina 22), ki se lahko poraja edinole iz opisane genealogije otroške čistosti. Kakor je bilo z utelešenjem za Merleau-Pontyja nenadoma vse spremenjeno, tako je bilo pri Claudelu z mislijo o nesmrtnosti otroka morda še radikalneje že mišljeno nekaj, kar je bilo $s$ pozabo ideje rojstvenosti in z njo povezane ideje otroka zakrito stoletja in je zdaj v svetlobi njegovega Magnifikata zasijalo na povsem nov način. Claudel s svojimi pesniškimi premisleki odkrije za nas ključno misel: njegov otrok se je rodil materi, tako kot se je Jezus rodil Mariji, ženski in po Irigaray soodrešiteljici sveta. Toda tako o Marijinem kakor tudi o Jezusovem otroštvu ne vemo veliko. O Mariji kot deklici čudovito pesni Rilke, ki v svojem ciklusu Marijino življenje opisuje tako njeno rojstvo kakor tudi njeno mladost, in, kar je izjemno, nakazuje na paradoks rojstva Boga, ki je sprva pred njo le majhen otrok:

O kaj angele moralo je stati, da zapeli niso iznenada, kot zajočě̌ saj so vendar vedeli: $v$ tej noči dečku se rodi mati, Enemu, ki se kmalu bo pojavil.

$[\ldots]$

(Otrok, drobna deklica bila je med ženami.)

$[\ldots]$

Glej, Bog, ki srdíl se je nad ljudstvi,

blag postaja in $\mathrm{v}$ tebi gre na svet.

Si si zamišljala ga večjega? (Rilke, Marijino 9, 16, 35)

Med apokrifnimi deli, ki opisujejo Kristusovo otroštvo, je gotovo na posebnem mestu Tomažev Evangelij o Jezusovem otroštvu iz 2. stoletja, v katerem najdemo izjemna pričevanja o Jezusovem delovanju, v času, ko je bil še otrok (o Marijinem otroštvu govori Jakobov Protoevangelij). Evangelij se začne z izjemno priliko o tem, kako je Otrok Jezus vzel blato in iz njega naredil vrabce. Četudi je v tekstu poudarek na tem, kako je $s$ tem čudežem oskrunil soboto, je $\mathrm{v}$ ozadju tega dejanja nedvomno Jezusova elementarno-respiratorna povezanost $\mathrm{z}$ vsem, kar biva, vključno z elementarnimi svetovi zemlje (blato) in zraka (ptice): Bachelard je $\mathrm{v}$ svoji analizi sanj in njihovih povezav z elementom zraka vedel, da so ptice (oziroma njihova krila) eden najpomembnejših simbolov dinamične imaginacije - to je ustvarjanja nečesa novega, prinašanja v svet nečesa, česar še ni bilo, sestavljanja novega sveta iz njegovih gradnikov-elementov, ter $s$ tem tudi otroštva, otroške igre in mladosti. Jezusa moramo zato videti kot mladega Boga, Boga, ki se je pojavil v 
otroškem telesu, in ki je tako paradigma nove (po)etične imaginacije (prim. Mt 18, 1-5). Kot bi rekel Bachelard - v povezavi s sanjami o pticah in letenju »instinktivno čutimo, da bodo naša telesa na ravni blaženosti nagrajena z zmožnostjo potovati skozi prostor tako kot ptice potujejo po zraku“ (Bachelard, Air 67). ${ }^{20}$

Cetudi se v Jezusovem razmerju do ljudi v okviru pripovedi iz Tomaževega Evangelija o Jezusovem otroštvu morda na prvi pogled zdi, da se Otrok Jezus obnaša nenavadno maščevalno (enega otroka za kazen posuši, drugega ubije, spet drugič umre učitelj, ki udari Jezusa - in o Jezusu se tako širi glas, da umro vsi, ki ga razjezijo), so pod obzorjem ideje kozmične pravičnosti vsa njegova opisana dejanja povezana z idejo otroka ter zaščito življenja. ${ }^{21}$ To se najlepše vidi v odlomku, v katerem mladi Jezus izve, da je v Jožefovi soseščini zbolel in umrl otrok. Takole pravi Evangelij:

Našel je mrtvega otroka, se dotaknil njegovih prsi in rekel: „Dete, rečem ti, ne umri, temveč živi in bodi s svojo materjo." In [otrok] je takoj pogledal in se zasmejal. Njegovi materi pa je dejal: „Vzemi svojega otroka, daj mu mleka in se me spominjaj.« [...] Jezus pa je spet šel ven in se igral z otroki. (Zgodnjekrš́anski spisi 1174)

Jezus se tako nahaja $\mathrm{v}$ najbližji bližini tistega, kar smo pri branju Hölderlina in Heideggra navezali na dar, ki ga v svet prinašajo ženske kot nosilke svetega diha rojstvenosti - tako simbola sodihanja matere in otroka v maternici kakor tudi širše sodihanja v okviru Svete Trojice. ${ }^{22}$ V Marijini skrivnosti smo videli, da je bilo »iz ženskega dihanja rojeno

20 „Ptica, ki je ustvarjena, da bi živela v najčistejšem in najbolj razredčenem elementu, je nujno sklepna in najčudovitejša izmed vseh oblik stvarstva" (Bachelard, Air 69). Glej tu odlično razpravo Mary Dzon. Dzonova poudarja, kako je krščanstvo edino izmed treh velikih monoteističnih verstev dovolilo, da se je Bog na svetu pojavil kot otrok. Obenem lucidno ugotavlja: »In creating these birds the child Jesus may be seen as founding a proto-Christian community, evangelical in nature and unburdened by constraints." (Dzon 198) V razmerju do ideje Boga kot otroka lahko omenimo še Buddho Gautamo, o katerem v okviru budistične tradicije obstajajo različne prilike o njegovem otroštvu ter o nadnaravnih sposobnostih, ki jih je imel že kot otrok.

${ }^{21}$ Jezus tako kaznuje otroka, ki razdeja luže, v katere je Jezus zbral vode (tj. življenja; podobno zgodbo najdemo v 26. poglavju Psevdo-Matejevega evangelija); kaznuje tudi otroka, ki ga udari oziroma v varianti vanj vrže kamen; potem kaznuje učitelja, ki Jezusa (kot otroka!) udari po glavi. V vseh primerih prilike na radikalno teološko-etični način govorijo o tem, da Jezus absolutno zaščiti življenje in otroke pred zlom tega sveta.

${ }^{22} \mathrm{O}$ tem gl. Antigonine sestre ter naše premisleke o Marijini matrici femininosti v okviru trinitarične misli same. 
moško" (Irigaray, Marijina 14) in v Tomaževem Evangeliju o Jezusovem otroštvu, kako Jezus "kot otrok" zaščiti sveto vez matere in dojenčka vez, ki je v skladu z nenapisanimi postavami ne sme raniti nobeno zlo sveta. Zdi se, da je Hölderlin želel povedati prav to, ko je v Himni Madoni v verzih 71-73 Marijo postavil v najtesnejšo zvezo z mladostjo ter zaščito vsega, kar je, začenši z mladimi poganjki, rastlinami, ki še potrebujejo zaščito:

\author{
Zato jih obvaruj, \\ ti nebeščanka, \\ te mlade rastline ... (Hölderlin, Sämtliche 221)
}

Posebej pa to velja za verz, ko zdaj pesnik pravi - in s tem povzema svojo alternativno, če lahko tako rečemo, varianto nauka o teodiceji: "Nič [od vsega tega] ni, zlo (Nichts ists, das Böse)." (220)

Odnos med Jezusom in Marijo je tako odnos horizontalne genealoške ljubezni: med njima je spletena sveta vez življenja, ki je ne more pretrgati niti smrt, o čemer čudovito pričuje ena izmed zgodb o Marijinem vnebovzetju. V okviru različnih pripovedi pozne bizantinske tradicije, ki obravnavajo Marijino vnebovzetje, najdemo $\mathrm{v}$ homiliji Sv. Janeza Damaščana opis trenutka, ko je Marija zaspala, čemur je sledilo njeno vnebovzetje. Jezus se iz nebes spusti na ta svet in kar sledi, je izjemno:

Gospod jo je objel, vzel je njeno sveto dušo in jo položil v Mihaelove roke ter jo ovil v nepopisno sijajne povoje. Apostoli smo videli Marijino dušo, ko je bila izročena Mihaelu: imela je popolno človeško obliko, le da ni posedovala potez moškega ali ženske, bila je zgolj podoba celega telesa in sedemkrat bolj bela. (Shoemaker 365)

Jezus kot Marijin sin zdaj sprejme njeno dušo, ki ima, kar je za nas izjemno - v tej pripovedi "podobo v belo oblečenega otroka" (Shoemaker 38). To neverjetno pričevanje (»le da ni posedovala potez moškega ali ženske«) kaže tako pritrdilno kakor per negationem na centralnost temeljnih generacijskih in spolnih rodov in odnosov v kozmično-teološkem smislu, in odpira možnost interpretacije Marijinega vnebovzetja, potem, ko je zaspala (in ne umrla), na povsem nov način. Če je bila Marija v nosečnosti (ko je z njim delila svoj dih in tako vstopila v ta svet kot njegova soodrešiteljica) in Jezusovem zgodnjem otroštvu tista, ki mu je prizanašala kot otroku in skrbno-materinsko varovala njegov sveti spanec, je Jezus zdaj tisti, ki jo varuje na njeni poti v nebesa, in skozi spanje $\mathrm{v}$ njeno posmrtno življenje. Ta popolni 
vzajemni odnos med Marijo in Jezusom - v dvojni konstelaciji Marije in Jezusa kot hkrati dveh staršev in dveh otrok v popolni vzajemnosti njunih vlog, tako zaznamuje našo idejo otroka ter z njim povezane absolutne svetosti otroškega spanca, etike miru, in časa odrešenja.

Za sklep se vrnimo še k Hölderlinovi Himni Madoni. Hölderlin je kot pesnik začutil potrebo po rehabilitaciji in s tem povezani remitologizaciji ženskega počela v okviru maskulinih matric grško-judovsko-krščanskega (ter tudi indoevropskega - germanskega) sveta. Da bi se v ta svet bogov, ki v dobi Očetovske paradigme še niso bili v celoti razločeni od srda in nasilja, lahko rodil nov Bog kot utelešenje Ljubezni - sprva kot novorojenček, in potem kot otrok - je bila potrebna žensko-materinska zaščita, ki jo je lahko novemu in porajajočemu se bogu nudila edinole Marija, Jezusova mati in kozmična matrica Ljubezni. Skozi sinhronistični princip ženskega božanstva, ko se v Mariji hkrati zrcalijo liki Gaje, pa tudi drugih grških boginj zaščitnic otrok (kot so Erinije) ter drugih boginj ljubezni, je slednjič mogoče potegniti vzporednico tudi z Antigono kot Marijino vrstnico, le da prebivajočo skozi objokavanje brata in ne sina, a tudi delujoče pod okrožjem brezpogojne ljubezni in ne srda. Zato naj sklenemo ta premislek z navezavo na izjemno Julio Kristevo, ki se takole dotakne odnosa med dvema mladima dekletoma - Marijo in Antigono - in Jezusom kot Marijinim otrokom in Antigoninim "genealoškim bratom«, ki vsi v okviru paradigme rojstvenosti ščitijo matere in njihove bodoče otroke (ter brate in sestre):

Kristus in Marija, vsak zase in skupaj, kratko malo prepoznavata Antigonino suvereno lucidnost [...] In pozivata vse ženske, naravne matere [človeške] vrste, naj ne zaustavljajo toka rojevanja otrok, temveč naj se jima (Jezusu in Mariji) pridružijo na enem od možnih presečišč med grškim in judovskim spominom. [...] Devica Marija izpelje ta premik veličastno, z večno vrnitvijo, ki doseže vrhunec v Pieta, ki jo povezuje z Jezusom. (Kristeva 225)

Antigona ni mogla imeti otrok, saj je svoje življenje žrtvovala za zavarovanje najstarejših ali praetičnih redov prebivanja. Vendar se $s$ svojim dejanjem vseeno nahaja v okrožju etike rojstvenosti: $s$ tem, ko je radikalno etično zaščitila bratov pokop, je zavarovala staro rojstveno pravico, izvirajočo iz njenega izvornega matriksialnega sodeljenja iste materine maternice $\mathrm{z}$ bratom, ki ga zdaj ni več na tem svetu. $\mathrm{O}$ tem ptiča tudi odlomek iz Sofoklove Antigone, ko le-ta opisuje njen prihod 
pred stražo in v katerem je Antigonina žalost neposredno postavljena v okrožje materine izgube otrok(a):

In ko čez dolgo se polegel je vihar, zagledali smo to dekle, ki je na glas jokalo, presunljivo kakor ptica, ko zagleda prazno gnezdo, a mladičev ni. (Sofokles 49)

Antigona torej tudi kot ptičja mati ... V tem je slednjič lahko nakazana njena tesna bližina z Marijo in Jezusom, zlasti kakor se ti božanski liki pojavljajo v okviru Hölderlinovega pesništva, ki je želelo doseči poravnavo starih grških in judovsko-krščanskih redov rojstvenosti, prebivanja v miru, in ljubezni.

\section{LITERATURA}

Ajshil. Oresteja. Prev. M. Marinčič. Ljubljana: Modrijan, 2008.

Bachelard, Gaston. L'air et les songes: essai sur l'imagination du mouvement. Paris: Librairie José Corti, 1992.

Bachelard, Gaston. Air and Dreams: An Essay on the Imagination of Movement. Tretja izdaja. Prev. Edith R. Farrell in C. Frederick Farrell. Dallas: The Dallas Institute of Humanities and Culture, 2011.

Ben Simpson, Christopher. Merleau-Ponty and Theology. London: Bloomsbury, 2014. Berndtson, Petri. »The Inspiration and the Expiration of Being: The Immense Lung and the Cosmic Breathing as the Sources of Drams, Poetry and Philosophy". Thinking in Dialogue with Humanities: Paths into the Phenomenology of MerleauPonty. Ur. Karel Novotný, Taylor S. Hammer in Petr Špecián. Bukarešta: Zeta Books, 2011. 281-293.

Berndtson, Petri. Phenomenological Ontology of Breathing. Doktorska disertacija. Univerza v Jyväskyli, 2018.

Böschenstein, Renate. "Hölderlins allegorische Ausdrucksform, untersucht an der Hymne ,An die Madonna'". Jenseits des Idealismus. Hölderlins letzte Homburger Jahre (1804-1806). Ur. Christoph Jamme in Otto Pöggeler. Bonn: Bouvier Verlag, 1988. 181-209.

Bruno, Giordano. Cause, Principle and Unity, And Essays on Magic. Prev. Richard J. Blackwell. Cambridge: Cambridge University Press, 1998.

Claudel, Paul. Sejalec božje mere. Prev. Marko Marinčič. Ljubljana: Mladinska knjiga, 1993.

Dzon, Mary. "Jesus and the Birds in Medieval Abrahamic Traditions«. Traditio 66 (2011): 189-230.

Heidegger, Martin. Na poti do govorice. Prev. Dean Komel et al. Ljubljana: Slovenska matica, 1995.

Heidegger, Martin. Razjasnjenja ob Hölderlinovem pesništvu. Prev. Vid Snoj. Ljubljana: Nova revija, 2001.

Heidegger, Martin. Predavanja in sestavki. Prev. Tine Hribar et al. Ljubljana: Slovenska matica, 2003. 
Heine, Stefanie. Poetics of Breathing: Modern Literature Syncope. New York, NY: SUNY Press, 2021.

Hölderlin, Friedrich. Hölderlin. Prev. Niko Grafenauer. Ljubljana: Mladinska knjiga, 1978.

Hölderlin, Friedrich. Sämtliche Werke. Bd. 2, Gedichte nach 1800. Ur. Friedrich Beissner, Adolf Beck in Ute Oelman. Stuttgart: W. Kohlhammer; J. G. Cotta, 1953.

Hölderlin, Friedrich. Pozne himne. Prev. Vid Snoj. Ljubljana: KUD Logos, 2006.

Irigaray, Luce. Marijina skrivnost. Prev. Anton Mlinar. Novo mesto: Goga, 2012.

Irigaray, Luce. To Be Born: Genesis of a New Human Being. New York, NY; London: Palgrave, 2017.

Jonas, Hans. Das Prinzip Verantwortung. Frankfurt am Main: Suhrkamp, 2003.

Kristeva, Julia. "Antigone: Limit and Horizon«. Feminist Readings of Antigone. Ur. Fanny Söderbäck. Albany, NY: SUNY Press, 2010. 215-30.

Medvešček-Klančar, Pavel. Iz nevidne strani neba. Razkrite skrivnosti staroverstva. Ljubljana: ZRC SAZU, 2015.

Merleau-Ponty, Maurice. Résumés de Cours, Collége de France 1952-1960. Paris: Éditions Gallimard, 1968.

Merleau-Ponty, Maurice. La Nature: Notes, course de Collège de France. Paris: Éditions du Seuil, 1995.

Merleau-Ponty, Maurice. "The Child's Relation with Others«. The Primacy of Perception. Ur. James M. Edie. Evanston, IL: Northwestern University Press, 1964. 98-155.

Merleau-Ponty, Maurice. "Themes from the Lectures at the Collège de France (19521960)«. In Praise of philosophy and Other Essays. Prev. John O'Neill. Evanston, IL: Northwestem University Press, 1988. 71-199.

Merleau-Ponty, Maurice. Nature: Course Notes from the Collège de France. Prev. Robert Vallier. Evanston, IL: Northwestem University Press, 1995.

Merleau-Ponty, Maurice. Fenomenologija zaznave. Prev. Špela Žakelj. Ljubljana: Beletrina, 2006.

Nietzsche, Friedrich. Tako je govoril Zaratustra. Prev. Janko Moder. Ljubljana: Slovenska matica, 1999.

Otto, Walter F. Bogovi Grčije: Podoba božanskega v zrcalu grškega duha. Prev. Samo Krušič in Alfred Leskovec. Ljubljana: Nova revija, 1998.

Rilke, Rainer Maria. »Soneti Orfeju«. Prev. Kajetan Kovič. Kaplje 66 (1966): 73.

Rilke, Rainer Maria. Marijino življenje. Prev. Gorazd Kocjančič. Ljubljana: KUD Logos, 2006.

Saint Aubert, Emmanuel. „L'Incarnation change tout: Merleau-Ponty critique de la théologie explicative«. Archives de Philosophie 71.3 (2008): 371-405.

Shoemaker, Stephen J., ur. Ancient Traditions of the Virgin Mary's Dormition and Assumption. Oxford: Oxford University Press, 2002.

Sofokles. Antigone. Prev. Ivan Hribovšek. Ljubljana: Družina, 2014.

Škof, Lenart. Etika diha in atmosfera politike. Ljubljana: Slovenska matica, 2013.

Škof, Lenart. "Schellingova Clara: skice za ontologijo ljubezni«. Primerjalna književnost 40.3 (2017): 69-86.

Škof, Lenart. Antigonine sestre: o matrici ljubezni. Ljubljana: Slovenska matica, 2018.

Škof, Lenart. "Naproti Tretji dobi ali o spravi med etiko in teologijo". Misli svetlobe in senc: Razprave o filozofskem delu Marka Uršiča. Ur. Maja Malec in Olga Markič. Ljubljana: Znanstvena založba Filozofske fakultete, 2021. 73-81.

Zgodnjekrščanski spisi. Ur. Klaus Berger in Christiane Nord. Ur. slovenske izdaje Gorazd Kocjančič in Vid Snoj. Celje; Ljubljana: Celjska Mohorjeva družba, 2015. 


\section{Sacred Night of the Sleep, the Idea of a Child, and Respiratory Poetics of Peace}

Keywords: literature and the idea of child / poetics of peace / Mary and Jesus / Hölderlin, Friedrich / Claudel, Paul / Bachelard, Gaston / Heidegger, Martin / Irigaray, Luce

This article deals with Hölderlin's, Claudel's, and Bachelard's poetic imagination in light of the idea of child, the sacredness of the child's sleep, and related respiratory (po)ethics. In the first part, we are analysing ancient genealogies of natality and femininity as they are represented within selected Hölderlin's hymns - in the forefront of our readings is his unfinished Hymn to Madonna. Heidegger's philosophy of natality and his elemental thought is also evaluated and interpreted in this part. This is followed in the second part by our presentation of Bachelard's poetic imagination of sleep and the related idea of the cosmic cradle, also as related to the respiratory rhythms of sleep and rhythms of cosmos. Finally, in the third part of the paper, on the trace of Claudel's idea of the immortality of the child, especially as presented in his Magnifikat ode, and under the horizon of the thought of Luce Irigaray, we are entering into a more specific Christian setting of our thinking. In the light of the idea of the child, we are discussing the relationality between Mary and Jesus and finally proposing a new ethical horizon, comprising the ideas of natality, child, and poetics of peace.

1.01 Izvirni znanstveni članek / Original scientific article

UDK 82.091:1

DOI: https://doi.org/10.3986/pkn.v44.i3.03 